\title{
A Lacanian Interpretation of Beloved's Subjectivity
}

\author{
Jun SHEN \\ Zhongzhou University, No. 6 Yingcai Road, Zhengzhou, Henan, China, 450044 \\ Email: shenjunzhzhu@163.com
}

Keywords: Subjectivity, Unconscious, Other, Discourse.

\begin{abstract}
This paper aims to interpret Toni Morrison's novel Beloved and examine the subjectivity of the controversial character Beloved in the framework of Lacanian subject theory, revealing her subjectivity is not shaped by Morrison in Cartesian paradigm and she is actually mirroring the unconscious of Sethe, Denver, the black community and the whole suffering history of the black people.
\end{abstract}

\section{Introduction}

Toni Morrison's novel Beloved, since its publication, has attracted the attention of literary critics in the whole world. Its narrative strategies, African traditions of black people and the psychological trauma left by slavery all become the exploring field of researchers. Among the broad research scope, psychoanalytic interpretation is no doubt a preference in understanding the development of characters in the novel, with Beloved being the most controversial one. Behaving like a baby instead of a normal girl in her twenties, Beloved cannot deal with everyday affairs and only possesses limited language competence. Compared with her sister Denver who seeks help from the black community and her mother Sethe and step father Paul D. going forward hand in hand to a new life, it seems that she has never gained her subjectivity in the novel. In fact, Beloved is not developed by Morrison as a conscious subject in Cartesian philosophy who knows clearly her identity. Lacan's subject of the unconscious to some extent seems more applicable to explanation for her behaviors and subjectivity in the narrative.

Lacan's dictum "the unconscious is the discourse of the Other" can be understood in many ways. The most important meaning is that "one should see in the unconscious the effects of speech on the subject" [1] 126. More precisely, the unconscious is the effects of the signifiers on the subjects, in that the signifier is what is repressed and what returns in the formation of the unconscious, which can be reflected in the slip of the tongue, dreams, and psychotic symptoms, etc. Morrison's Beloved seems to have possessed all such abnormal qualities. Shaped by the signifiers, she could be interpreted as discourse of the Other in Lacanian terms---the discourse of the whole language culture, synchronically and diachronically.

\section{Sethe's Discourse}

According to Lacan, the self or ego, or the conscious originates from the imaginary field. Due to the imaginary mirror image identification, what one sees and thinks logically and reasonably are misrecognitions. In other words, self is the result of misconception and subjectivity does not exist in a coherent self but in the unconscious that is constructed like language. The first and foremost Other for all human subjects is the 
mother who plays an important role in the Imaginary before the interference of language.

As a slave, Sethe has experienced separation from her own mother in her childhood, the cruel physical and psychological torture in the plantation Sweet Home, the hard process of running away in pregnancy, the murder of her baby daughter Beloved, and the isolation and blame from the black community as well as misunderstandings of her living children and her lover Paul D. She is a typical signifier in the symbolic society of slavery, and she represents the extremely oppressed figure at the time. Sethe kills Beloved, according to Stamp Paid, because she is "trying to out-hurt the hurters" and "she loves those children" [2]243. Loving as a slave, according to Paul D whom Stamp Paid is trying to persuade with his assessment of Sethe's motivation, means "loving small and in secret" [2]221, loving in an unobvious way so that whatever is loved does not become part of a technique of punishment.

Sethe is reluctant to mention her past to anybody including her daughter Denver and her mother-in-law Baby Suggs as well as Paul D. They are all her closest relatives and have shared some parts of the miserable life. Only Beloved is the exception---she likes to hear Sethe's stories and Sethe enjoys sharing her past with her. In the narrative, the reincarnated Beloved is inseparable from Sethe and is always eager to hear Sethe's story which is too miserable to recollect and recall. Beloved is eager to hear Sethe's story, and meanwhile Sethe is willing to share her story with Beloved, because Beloved is not only the witness of the infanticide, but also the victim of the incident. She has the right to hear the story and to ask Sethe the reason for sawing the black infant's throat. She reminds Sethe of her own mother and mother tongue, and forces Sethe to recollect the disremembered story in the past. When Sethe is asked by Beloved to "tell me your diamonds" [2] 58, Beloved not only intends to hear the story of how Mrs. Garner has given diamond earring to Sethe for a wedding present, but also she is also offering to turn the dark stories of Sethe's past into something shining and valuable. Therefore, the telling of the story about diamonds brings Sethe pleasure. Sethe hides herself in the past and isolates herself from both the past and the future, from both her relatives and black community. It is Beloved's arrival in the corporeal form that enables Sethe to face the unspeakable past bravely and becomes a coherent conscious subject. Sethe's repressed past is locked in her just like Paul D's tobacco tin. When she eventually realizes Beloved is her dead daughter coming back, she has a feeling as if some buried treasure has been found.

Beloved's reincarnation awakens the past experience Sethe has buried deep in her memory. Beloved, the murdered girl, is the repressed past of Sethe's guilt and loss, and at the same time Beloved arouses Sethe's past-telling. As Amy Denver says, "anything dead coming back to life hurts" [2]75, and Sethe's endeavor to prove her love for Beloved and to gain Beloved's forgiveness nearly destroys Sethe. In that sense, Beloved is Sethe's discourse which consists of the miserable past and the foreseeable new life in the future. Therefore, Morrison's depiction of the incoherent character Beloved reflects the deeper discourse of the mother Sethe.

\section{Denver's Discourse}

When Sethe first sees the reincarnated Beloved, her "bladder [fills] to capacity" [2]51. She runs immediately to the outhouse but does not make it. Later, in a retrospective moment, Sethe remembers this scene in trying to discover who Beloved will be. It should be noticed that at that moment instead of remembering the birth of Beloved 
Sethe recalls the birth of Denver. Denver likes hearing her birth story very much, in which she is born on the river which is the boundary of slavery and freedom. Therefore, Denver inherits both the tradition of slavery and freedom during the flight of Sethe. When the schoolteacher arrives at 124 to claim Sethe and her children, Denver drinks her sister's blood mixed with her mother's milk and then she goes to the jail together with her mother.

As another mirror of Sethe's repressed stories in the past, Denver goes deaf when she is asked about the time in jail. From then on Denver lives in seclusion, with only Sethe, Baby Suggs, and the baby ghost as companions. This remains until Beloved comes to their home. In her lonely isolation from the world, Denver is also trapped in her mother's past. Sethe intentionally keeps Denver in the dark: "as for Denver, the job, Sethe had of keeping her from the past that was still waiting for her was all that mattered" [2]42. However, the unacknowledged past prevents Denver from moving into the future, and she cannot grow mature without the acknowledgment of the past. She is jealous of her mother's past, and her exclusion from the past increases her loneliness and bitterness. Beloved, on the other hand, thrives on stories of the past, on pulling details of her past from Sethe, and Denver's love for Beloved forces her to confront the past she hates.

Although knowing the past is a painful process for both herself and her relatives, Denver has to settle this problem in great efforts. First of all, Denver experiences the past when she tells her birth story to Beloved. When she repeats the story, "Denver [is] seeing it now and feeling it---through Beloved. Feeling how it must have felt to her mother. Seeing how it must have looked" [2]78. Yet Denver does not completely remember her own past and her mother's until she undergoes the psychological monologues in the second part of the novel.

In the novel, Morrison devotes several pages to describing the inseparable relationship among Sethe, Denver, and Beloved. Most contents emerge from the minds of them after Beloved moves Paul D. out and they are left alone. Sethe recognizes Beloved as her murdered daughter and is absorbed in an attempt to prove her love and atone for the murder, while Denver tries her best to stay inside the circle of possession Sethe and Beloved have created. Sethe first proclaims her possession of her daughter Beloved, then Denver of her sister Beloved, and then Beloved of her mother. While Denver is possessed by the past, she remembers everything---her own past and her mother's, the fear of her mother as a child murderer, and the imaginary reunions with her father. This kind of possession breaks through her seclusion and grants her an experience of the past which can lead her into the future. After the winter of possession, Denver notices she has to go out of the house in order to save her mother from madness and from the ravenous Beloved. In the last moment of fear as she reaches the door, Baby Suggs speaks to her and encourages her to seek help from the black community.

Denver tells the community that Beloved, the murdered baby, has returned to punish Sethe. She learns to repeal to the community because she knows only through the black community, can Sethe be saved and get her wound healed. Meanwhile, Denver's personal healing is attested. After this crisis, Denver becomes mature as a normal subject in the black community. She knows now her shared history--- her family's, her community's, as well as her culture's. Such knowledge is gained to a large extent through her incarnated daughter Beloved who witnesses and promotes Denver's growth In that sense, Beloved is a vital signifier in constructing the subjectivity of Denver and she is created by Morrison for Denver. 


\section{Discourse of the Black Community}

In addition to Sethe and Denver, Beloved also witnesses or acquaints herself with other people's experience in the black community. As a whole ethnical group, it has experienced too much unspeakable experience under slavery, which is also depicted by Morrison through Beloved, her unspeakable sufferings mirroring miseries and tortures imprinted in the unconscious of the whole black community.

Paul D. is a typical slave in the black community. At the beginning of the narrative, Paul D. visits Sethe and wants to live a new life together with her. In the interaction with Sethe and other blacks, he tries to forget the shameful past and becomes an independent man who is liked and respected in the black community. However, this is just his fantasy. His visit soon provokes Denver's resistance and he gets trouble in communicating with Sethe and Denver. His dream to construct a family disillusions, which proves that the black cannot construct a family and face the happy future by forgetting the past. They have to courageously confront the past. Beloved's reincarnation also reminds Paul D. of the shameful past. Meanwhile, her seduction awakens Paul D's shamefulness that he has experienced in the Sweet Home and the succeeding life of flight which is even more miserable and unspeakable.

Ella, another ex-slave who is loved by no one and who considers "love a serious disability" [2]256, lives by the simple dictum "don't love nothing"[2]92. It is hinted that Ella has also committed infanticide. By placing such a frame around Sethe's story, Morrison insists on the impossibility of judging an action without reference to the terms of its enactment---the wrongness of assuming a trans-historical ethic outside a particular historical moment. The community responds to Sethe's haunted family in three ways: "those that believed the worst; those that believed none of it; and those, like Ella, who thought it through" [2]255. Ella like the incarnated Beloved also has a place in the larger narrative of slavery. Her puberty is spent "in a house where she [is] shared by father and son, whom she [calls] 'the lowest yet'. It is hinted in the novel Beloved seems to have a similar experience. It was the 'lowest yet' who gave her a disgust for sex and against whom she measured all atrocities" [2]256. Ella's personal past has hints of infanticide in it too:

Ella had been beaten every way but down. She remembered the bottom teeth she had lost to the brake and the scars from the bell were thick as rope around her waist. She had delivered, but would not nurse, a hairy white thing, fathered by 'the lowest yet.' It lived five days never making a sound. The idea of that pup coming back to whip her too set her jaw working. [2]258-59

By registering her narrative within a framework of determinism and forgiveness, Ella has learned how to free herself. She offers that possibility to Sethe. For twenty-eight days, Sethe has been free---the time between crossing the Ohio River and the time she kills her baby daughter. Sethe has known then that "freeing yourself [is] one thing; claiming ownership of that freed self [is] another" [2] 95 . In those twenty-eight days, she has claimed herself. After murdering Beloved, she loses that claim. Ella, by exorcising Beloved, by not allowing the past to consume the present, offers Sethe the opportunity to reclaim herself. In the end Sethe does, and does so by an act of community.

Sethe, Paul D., and Denver in particular, all get certain freedom with the help of the community where their root exists. Beloved is driven away. Yet the act of exorcism conducted by the community, to a certain extent, is the determination of the black to unite together and bravely face the miseries in the past. In this sense, Beloved symbolizes all shameful past of the black community as an ethnical group of slaves. 


\section{Discourse of the History}

Beloved, the incarnation of the ghost of the murdered daughter, is the most obvious revisionist construction in Morrison's novel. Through Beloved, she signifies on history by resurrecting one of its anonymous victims. In that sense, Beloved can be interpreted in the historical framework. Lacan's theory has developed Freudian psychoanalysis and is to a certain extent related to the historical elements. Fredric Jameson asserts:

Lacan's work with its emphasis on the "constitution of the subject" displaces the problematic of orthodox Freudianism from models of unconscious processes or blockages toward an account of the formation of the subject and its constitutive illusions which, though still genetic in Lacan himself and couched in terms of the individual biological subject, is not incompatible with a broader historical framework. [3]135

When Beloved comes back to haunt Sethe for murdering her, Beloved becomes the incarnated memory of Sethe's guilt. Moreover, she is nothing but guilt, a symbol of an unrelenting criticism of the dehumanizing function of the institution of slavery.

Beloved's resistance to being a normal subject in the symbolic order is the same as Sethe's unwillingness to tell her past stories, Paul D's keeping the rusted tobacco tin, and Baby Suggs's "beating the past at bay". For all black slaves, the past is too terrible to recollect and the symbolic order is too evil to identify with. The past experiences of the slaves are unspeakable. The black people try to adopt a variety of ways to disremember the past. Beloved is wandering on the verge of the symbolic order and hesitates to completely enter into it, because once she gets definite meaning of her past experience, it is unbearable.

Since Morrison does not identify these scattered perceptions as observations of life on a slave ship or tell how Beloved comes to be there or give any coordinates of time and place, readers are confused: they have no idea who is Beloved. Their confusion thus imitates the disorientation of the Africans who are thrown into the slave ships without explanation, suspended without boundaries in time and space.

The depiction of Beloved robs the reader of known demarcations; the baffling narrative "creates a linguistic equivalent of the Africans' loss of differentiation in an 'oceanic' space that 'unmade' cultural identities and erases even the lines between male and female, living and dead" [4]72. Readers who try to understand these unsettling images as metaphors for Beloved's passage from death to life can find a basis for doing so in the African American narrative tradition, which pictures the Middle Passage as a journey toward a horrific rebirth. Robert Hayden calls the Middle Passage a "voyage through death to life upon these shores" [5]54; Richard Wright remarks, "We millions of black folk who live in this land were born into Western civilization of a weird and paradoxical birth" [6]12. The nightmare collage of bodies piled on bodies in the slave ship, where it is hard to tell the living from the dead, would then figure Beloved's difficulty in discerning, in her transitional state, whether she is alive or dead, traveling toward death or toward life. But Morrison everywhere demands that readers confront the horrors of slavery "in the flesh" rather than at the comfortable distance of metaphor "I wanted that haunting not to be really a suggestion of being bedeviled by the past," she comments, "but to have it be incarnate" [7].

Morrison becomes explicitly historical with Beloved, investigating not just the general qualities of African American memory but also how people experience specific events. A neo-slave narrative in Beloved opens a historical trilogy of novels (the other twos are Jazz and Paradise) that extends the investigation of the black conscious and 
unconscious back to the Middle Passage, documenting not only Morrison's careful reading of slave texts but also how slavery necessarily lives in the present. Morrison's retelling invokes unbearable trauma, in which it is not clear whether death or life is preferable, and either could be imposed at any moment. According to Lacan, traumas are reflected in the unconscious hallucinations of the black slaves rather than in their reasonable conscious. To Morrison, Beloved is a daughter of the past history and all of the historical signs of slavery are mirrored by her.

\section{Conclusions}

As a descendant of black slaves, Beloved is eager to get rid of the baffling state of subjectivity, which is a problem haunting most of the black people. According to Lacanian psychoanalysis, self or ego is originally formed in the mirror stage by imaginary identification with mirror image. In order to gain a coherent self, Beloved attempts to identify with Denver, Sethe and other people around her. She fails. Her self-consciousness as Sethe's daughter is merely misrecognition, which not only misleads her relatives in the novel but also readers attempting to figure out her identity.

Beloved, assuming collective or multiple identities in the novel, has experienced the torture of murder in the period of reconstruction and inhuman treatment on the slave ship during the Middle Passage, both of which are "unspeakable" stories. Such traumas usually appear in hallucinations hidden in people's unconscious since they are "unspeakable". If Morrison prefers, she could use another chapter at the end of the novel saying clearly that Beloved is just hallucinations of the traumatized black and serves for mirroring and healing their trauma hidden in the unconscious, but she chooses to leave it for readers' reflection and interpretation.

\section{References}

[1] Lacan, Jacques. The Seminar of Jacques Lacan Book XI. Ed. Jacques-Alain Miller. Trans. Alan Sheridan. New York and London: W.W \& Norton Company. 1998.

[2] Morrison, Toni. Beloved. Beijing: Foreign Language Teaching and Research Press, 2000 .

[3] Jameson, Fredric. The Political Unconscious: Narrative as a Socially Symbolic Act. New York: Cornell University Press. 1981

[4] Spillers, Hortense. Diacritics 17 (1987): 65-81

[5] Hayden, Robert. "Middle Passage." Collected Works. New York: Liverright, 1985: 48-54

[6] Wright, Richard. Twelve Million Black Voices. New York: Thunder's Mouth, 1988

[7] Rothstein, Mervyn. "Toni Morrison, in Her New Novel, Defends Women." New York Times 26 Aug. 1987: C17. 